\title{
IMPLIKASI UNDANG-UNDANG NOMOR 5 TAHUN 1999 TENTANG LARANGAN PRAKTEK MONOPOLI DAN PERSAINGAN USAHA TIDAK SEHAT PADA PELAKU USAHA MIKRO KECIL DAN MENENGAH (UMKM) \\ (Implication of Law No. 5 of 1999 Concerning Prohibition of Monopoly and Unfair Competition in Micro, Small and Medium Businesses (MSMEs))
}

\author{
Ayup Suran Ningsih \\ Fakultas Hukum, Universitas Negeri Semarang \\ Gedung K, Kampus Sekaran Gunungpati, Semarang, 50229 \\ ayuupp@mail.unnes.ac.id
}

Tulisan Diterima: 12 Februari 2019; Direvisi: 15 Mei 2019; Disetujui Diterbitkan 13 Juni 2019 DOI: http://dx.doi.org/10.30641/dejure.2019.V19.207-215

\begin{abstract}
The Law No. 5 of 1999 regarding Prohibition of Monopoly and Unfair Business Competition Practices (Anti Monopoly Law) is the basis of the Indonesian policies adopted for dealing with unfair business competition Indonesia. The Anti-Monopoly Law has a specific regulatory system in addressing the relationship between the business competition and small businesses. Business competition policies and laws in Indonesia highly favor the MSMEs. All actions of MSM Entrepreneurs are excluded by Article 50 letter $h$ of Law No. 5 Year 1999. The law also prohibits large businesses from using their market powers in order to prevent the others (including the MSMEs) from doing businesses or other harmful practices. One of the objectives of this Law is to guarantee equal business opportunities for every entrepreneur. The issues of this research are the consequences of the exemptions given to the small-scale business entrepreneurs, potential violations by MSM Entrepreneurs in terms of business competition, and how to monitor the MSM Entrepreneurs in other countries. The method used in this research is the socio-legal approach. This method is an empirical research and problem approach by observing the existing rules and theories and then relate them with the facts or facts prevailing in the industry (public). The results of this research indicate that exemptions to small business entrepreneurs must not be absolute while relevant institutions/authorities must always conduct the supervisions. Exemptions do not guarantee that small businesses will not cheat or be unfair in its business competition. The exemptions possess a positive impact, the increase in the number of MSM Entrepreneurs, while at the same time its negative impact has been that the exemptions prevent the MSM Entrepreneurs from developing into big business entrepreneurs. The MSM Entrepreneurs may also potentially commit violations in terms of business competition such as pricing, boycotts, territorial division, agreements with foreign parties, and secret agreements. Thailand is a country that can be used as an example in the development and supervision of its MSMEs. Thailand has a MSMEs development system, i.e. one tamboon one product. Thailand has also several institutions/authorities taking care of MSMEs such as the Office of Small and Medium Enterprises (OSMEP), the Institute for Small and Medium Enterprises Development (ISMED), Competition Commission, and special banks for MSMEs, in addition to the central and regional governments.
\end{abstract}

Keywords: competition law; monopoly; unfair competition; implications of Law No. 5 of 1999; MSMEs. 


\section{ABSTRAK}

Undang-Undang Nomor 5 Tahun 1999 tentang Larangan Praktek Monopoli dan Persaingan Usaha Tidak Sehat (Undang-Undang Anti Monopoli) merupakan dasar kebijakan persaingan usaha di Indonesia. Undang-Undang Anti Monopoli memiliki sistem pengaturan yang khas dalam menyikapi hubungan persaingan usaha dan usaha kecil. Kebijakan dan hukum persaingan usaha di Indonesia berpihak kepada UMKM. Semua tindakan pelaku UMKM dikecualikan oleh Pasal 50 huruf h UndangUndang Nomor 5 Tahun 1999. Undang-Undang tersebut juga melarang pelaku usaha besar untuk menggunakan kekuatan pasarnya untuk menghambat pelaku usaha lain (termasuk UMKM) ataupun melakukan praktek lain yang merugikan. Salah satu tujuan Undang-Undang ini yaitu menjamin kesempatan berusaha yang sama bagi setiap pelaku usaha. Permasalahan dalam penelitian ini yaitu bagaimana implikasi atas pengecualian tersebut terhadap pelaku usaha kecil, pelanggaran-pelanggaran apasaja yang potensial dilakukan oleh pelaku UMKM dalam hal persaingan usaha, serta bagaimana pengawasan terhadap pelaku UMKM di negara lain. Metode pendekatan yang digunakan dalam penelitian ini adalah pendekatan sociolegal. Metode ini merupakan penelitian empiris dan pendekatan masalah melalui peraturan dan teori yang ada kemudian menghubungkannya dengan kenyataan atau fakta yang ada di lapangan (masyarakat). Hasil penelitian ini menunjukan bahwa pengecualian kepada pelaku usaha kecil tidak boleh bersifat mutlak atau absolut (absolute), harus tetap dilakukan pengawasan oleh lembaga-lembaga terkait. Pengecualian tidak menjamin pelaku usaha kecil tidak berbuat curang atau nakal dalam bersaing. Pengecualian tersebut memiliki implikasi positif yaitu bertambahnya jumlah pelaku UMKM dan implikasi negatif yaitu pelaku UMKM tidak ingin menjadi pelaku usaha besar. Pelaku UMKM berpotensi untuk melakukan pelanggaran dalam hal persaingan usaha seperti penetapan harga, boikot, pembagian wilayah, perjanjian dengan pihak luar negeri, dan perjanjian tertutup. Thailand menjadi negara yang bisa dijadikan contoh dalam pengembangan dan pengawasan UMKM. Thailand memiliki sistem pengembangan UMKM yaitu one tamboon one product. Thailand memiliki beberapa lembaga untuk UMKM seperti Office of Small and Medium Enterprises Promotion (OSMEP), Institute for Small and Medium Enterprises Development (ISMED), Competition Commission, dan Bank khusus untuk UMKM, serta pemerintah pusat dan daerah.

Kata Kunci: hukum persaingan usaha; monopoli; persaingan usaha tidak sehat; implikasi undang-undang nomor 5 tahun 1999; UMKM.

\section{PENDAHULUAN}

Persaingan dalam kegiatan usaha senafas dengan kegiatan usaha itu sendiri. Pada prinsipnya, setiap orang berhak menjual atau membeli barang atau jasa "apa”, "dengan siapa”, "berapa banyak” serta "bagaimana cara” produksi, inilah apa yang disebut ekonomi pasar. Sejalan dengan itu, perilaku dan struktur pasar terkadang tidak dapat diprediksi, sehingga tidak jarang pelaku usaha menimbulkan kecurangan, pembatasan yang menyababkan sebagian atau beberapa pelaku usaha merugi bahkan mati. ${ }^{1}$

Kuatnya dominasi negara-negara maju terhadap tata perekonomian dunia dan kuatnya pengaruh institusi supra-state, telah

1 Mustafa Kamal Rokan, Hukum Persaingan Usaha Teori dan Praktiknya di Indonesia Cetakan ke-2 (Jakarta: RajaGrafindo Persada, 2012), hal 1 mengakibatkan pemerintah Indonesia dengan “terpaksa” melakukan transplantasi hukum. Dengan demikian, karakter transplantasi hukum, khususnya yang terjadi dalam bidangbidang ekonomi, sebagian terjadi karena hegemoni negara-negara maju atau lembaga supra state maupun karena kesadaran penuh untuk melakukan pembaharuan hukum. ${ }^{2}$

Persaingan usaha yang sehat (fair competition) akan memberikan akibat positif bagi para pelaku usaha, sebab dapat menimbulkan motivasi atau rangsangan untuk meningkatkan efisiensi, produktivitas, inovasi, dan kualitas produk yang dihasilkannya. Selain menguntungkan bagi para pelaku usaha, tentu saja konsumen memperoleh manfaat dari persaingan usaha yang sehat itu, yakni adanya

2 Aristeus, S. (2018). Transplantasi Hukum Bisnis di Era Globalisasi Tantangan Bagi Indonesia. Jurnal Penelitian Hukum De Jure, 18(4), 513524, hal 519 
penurunan harga, banyak pilihan, dan peningkatan kualitas produk. Sebaliknya apabila terjadi persaingan usaha yang tidak sehat (unfair competition) antara pelaku usaha tentu berakibat negatif tidak saja bagi pelaku usaha dan konsumen, tetapi juga memberikan pengaruh negatif bagi perekonomian nasional. ${ }^{3}$

Pelaku usaha adalah subjek yang tidak dapat dilepaskan dari persaingan usaha itu sendiri. Pelaku usaha yang jumlah di akar rumput sangat banyak adalah pelaku Usaha Mikro Kecil dan Menengah (UMKM). Pelaku UMKM wajib hukumnya untuk mendapat perlindungan dari pemerintah. Keberadaan Undang-Undang Nomor 5 Tahun 1999 tentang Larangan Praktek Monopoli dan Persaingan Usaha Tidak Sehat (Undang-Undang Anti Monopoli) diharapkan dapat menjadi payung hukum perlindungan dan terjaminnya kepastian hukum bagi pelaku UMKM.

Usaha Mikro Kecil dan Menengah (UMKM) memainkan peran penting didalam pembangungan dan pertumbuhan ekonomi, tidak hanya di negara-negara sedang berkembang, tetapi juga di negara-negara maju. Pengecualian bagi usaha kecil yang diatur didalam Pasal 50 huruf (h) Undang-Undang Nomor 5 Tahun 1999 dimungkinkan karena UMKM tidak memiliki kemampuan yang kuat untuk bersaing dengan pelaku usaha besar. Hal ini disebabkan antara lain oleh permodalan UMKM yang lemah dan kemampuan sumber daya manusia (SDM) mereka yang sangat terbatas. $^{4}$

Pengecualian pelaku usaha kecil dari Undang-Undang Anti Monopoli juga dimaksudkan bahwa pengusaha kecil masih membutuhkan perlindungan agar dapat berkembang, serta karena alasan sosial bahwa posisi pengusaha kecil tersebut lemah sehingga dinilai tidak akan mungkin melakukan kegiatan monopoli. ${ }^{5}$

Salah satu tujuan pemberlakuan UndangUndang Anti Monopoli sesuai dalam Pasal 3 huruf (b) Undang-Undang Anti Monopoli adalah mewujudkan iklim usaha yang kondusif

3 Hermansyah, Pokok-Pokok Hukum Persaingan Usaha (Jakarta: Kencana, 2008), hal 9-10

4 Suyud Margono, Hukum Anti Monopoli (Jakarta: Sinar Grafika, 2009), hal 34

5 Mustafa Kamal Rokan, Op Cit, 2012) hal 260 melalui pengaturan persaingan usaha yang sehat, sehingga menjamin adanya kepastian kesempatan berusaha yang sama bagi pelaku usaha besar, pelaku usaha menengah, dan pelaku usaha kecil. Permasalahan dalam artikel ini yaitu mengakaji bagaimana implikasi atas pengecualian tersebut terhadap pelaku usaha kecil, pelanggaranpelanggaran apasaja yang potensial dilakukan oleh pelaku UMKM dalam hal persaingan usaha, serta bagaimana pengawasan terhadap pelaku UMKM di negara lain, yaitu Thailand.

\section{METODE PENELITIAN}

Metode pendekatan yang digunakan dalam penelitian artikel ini adalah socio legal research. Metode ini merupakan penelitian empiris $^{6}$ dan pendekatan masalah melalui peraturan dan teori yang ada kemudian menghubungkannya dengan kenyataan atau fakta yang ada di lapangan (masyarakat). ${ }^{7}$ Menurut Sulistyowati Irianto, penelitian socio legal research merupakan kajian terhadap hukum dengan menggunakan pendekatan ilmu hukum maupun ilmu sosial atau studi yang mereprentasi keterkaitan antara konteks dimana hukum berada. ${ }^{8}$

\section{PEMBAHASAN DAN ANALISIS}

\section{Implikasi atas Pengecualian Usaha Kecil terhadap Pelaku Usaha Kecil}

Dalam rangka mengkaji dan menganalisa perihal pelanggaran-pelanggaran dalam hukum persaingan dikenal beberapa teori pendekatan yang digunakan sebagai landasan penentuan penindakan pelanggaran-pelanggaran dalam Undang-Undang Anti Monopoli. Terdapat dua teori pendekatan utama yang digunakan dalam

6 Soetandyo Wignjosoebroto, Hukum: Paradigma, Metode dan Dinamika Masalahnya (Jakarta: Elsam \& Huma, 2002), hal 164

7 Ade Saptomo, Pokok-Pokok Metode Penelitian Hukum (Surabaya: Unessa University Press, 2007), hal 102

8 Sulistyowati Irianto, Sidharta, dkk, Metode Penelitian Hukum: Konstelasi dan Refleksi (Jakarta:Yayasan Pustaka Obor Indonesia, 2011), hal 173-175 
Hukum Persaingan Usaha yaitu teori Per Se Illegal dan teori Rule of Reason.

Per se illegal sebuah pendekatan dimana suatu perjanjian atau kegiatan usaha dilarang karena dampak dari perjanjian tersebut telah dianggap jelas dan pasti mengurangi atau menghilangkan persaingan. Dalam pendekatan ini pelaku usaha pelapor tidak perlu membuktikan adanya dampak suatu perjanjian yang dibuat oleh pelaku usaha pesaingnya. Bukti yang diperlukan adalah bahwa perjanjian yang dimaksud telah benar adanya atau bahwa kegiatan bisnis dimaksud telah benar-benar dilakukan oleh pelaku usaha pesaingnya. ${ }^{9}$

Pendekatan Rule of Reason adalah suatu doktrin yang dibangun berdasarkan penafsiran atas ketentuan Sherman Antitrust Act oleh Mahkamah Agung Amerika Serikat. Pendekatan ini adalah kebalikan dari pendekatan per se illegal. Pendekatan rule of reason adalah suatu pendekatan yang menentukan meskipun suatu perbuatan telah memenuhi rumusan undang-undang, namun jika ada alasan objektif yang dapat membenarkan perbuatan tersebut, maka perbuatan itu bukan merupakan pelanggaran. Artinya penerapan hukumnya tergantung pada akibat yang ditimbulkannya, apakah perbuatan itu telah menimbulkan praktik monopoli atau persaingan usaha tidak sehat, karena titik beratnya adalah unsur materiel dari perbuatannya. ${ }^{10}$ Jadi penerapan hukum dalam pendekatan rule of reason mempertimbangkan alasan-alasan mengapa dilakukannya suatu tindakan/suatu perbuatan oleh pelaku usaha.

Secara umum semangat diundangkan Undang-Undang Nomor 5 tahun 1999 dalam rangka mendorong persaingan yang sehat sehingga iklim dalam berusaha lebih fair dan kondusif untuk menjamin industri yang kompetitif bisa tumbuh dan berkembang serta kesejahteraan masyarakat lebih terjamin.

9 Ni Wayan Anggita Darmayoni and I Gede Yusa, "Merger Terkait Dengan Indikasi Penguasaan Pangsa Pasar Menurut Undang-Undang Nomor 5 Tahun 1999 Tentang Larangan Praktek Monopoli” (1999): 1-5.

10 Susanti Adi Nugroho, Hukum Persaingan Usaha di Indonesia dalam Teori dan Praktik serta Penerapan Hukumnya (Jakarta: Kencana, 2012), hal 711
Sesuai dengan ketentuan undang-undang maka hanya pelaku usaha besar dan menengah saja yang terkena larangan, karena UndangUndang Nomor 5 tahun 1999 secara tegas memberikan pengecualian kepada pelaku usaha kecil. Pemberian pengecualian kepada pelaku usaha kecil dari ketentuan-ketentuan yang ada dalam Undang-Undang Anti Monopoli menimbulkan suatu implikasi baik bagi pelaku usaha kecil tersebut maupun stakeholder lainnya yang terkait. Pemberian pengecualian ini merupakan suatu kebijakan persaingan usaha yang memberi manfaat untuk UMKM.

Implikasi atas pemberian pengecualian kepada pelaku usaha kecil dari ketentuanketentuan yang terdapat pada Undang-Undang Anti Monopoli yang pertama yaitu menimbulkan suatu keberanian untuk berusaha (membuka usahanya) bagi para pelaku UMKM di Indonesia. Pelaku UMKM merasa terlindungi dengan adanya pengecualian tersebut. Hal ini terbukti dengan meningkatnya jumlah pelaku UMKM di Indonesia. ${ }^{11}$

Tingginya tingkat pertumbuhan pelaku UMKM di Indonesia memberikan gambaran bahwa tujuan dari Undang-Undang Anti Monopoli yang tercantum dalam Pasal 3 huruf b tercapai. Pemerintah berhasil mewujudkan iklim usaha yang kondusif melalui pengaturan persaingan usaha yang sehat sehingga menjamin adanya kepastian kesempatan berusaha yang sama bagi pelaku usaha besar, pelaku usaha menengah, dan pelaku usaha kecil. UMKM tidak lagi dipandang sebagai pelaku usaha minoritas yang dipinggirkan. Terdapat kesinambungan antara pengecualian yang terdapat pada Undang-Undang Anti Monopoli dan perwujudan tujuan atas diundangkannya Undang-Undang Anti Monopoli.

Implikasi kedua dari adanya pengecualian bagi pelaku usaha kecil tersebut yaitu banyak pelaku usaha kecil tidak ingin menjadi pelaku usaha besar karena adanya pengecualian tersebut. ${ }^{12}$ Selain pemberian

11 diambil dari http://www.depkop.go.id/ diakses pada 25 November 2018 pukul 16:22 WIB

12 Data diperoleh dalam wawancara yang dilakukan dengan Mohammad Reza, SH, MH selaku Kepala Biro Hukum, Humas dan kerjasama KPPU pada 7 Januari 2018 pukul 11.30 WIB di kantor KPPU Jalan Ir. H. Juanda No. 36 Jakarta 
pengecualian atas ketentuan-ketentuan UndangUndang Anti Monopoli, banyak sekali insentif yang diberikan oleh Pemerintah kepada para pelaku usaha kecil antara lain berupa kebijakan pendanaan (modal usaha) dan keringanan pajak. Hal ini memberikan disinsentif kepada para pelaku usaha besar, oleh karena itu banyak pelaku UMKM yang tidak ingin menjadi pelaku usaha besar. Fenomena tersebut diterjemahkan oleh KPPU sebagai tantangan tersendiri yang memerlukan perlakukan khusus, karena perlakukan kepada para pelaku usaha kecil diibaratkan oleh KPPU sama saja dengan perilaku kepada anak kecil yang harus hati-hati dan penuh pertimbangan.

\section{Bentuk Pelanggaran yang Potensial dilakukan oleh Pelaku Usaha Mikro Kecil dan Menengah (UMKM)}

Dalam persaingan antar perusahaan terutama perusahaan besar dalam memperoleh keuntungan sering kali terjadi pelanggaran etika berbisnis, bahkan melanggar peraturan yang berlaku. Hal ini terbukti dengan meningkatnya jumlah kasus yang disidangkan oleh Komisi Pengawas Persaingan Usaha (KPPU). Pelanggaran etika bisnis dan persaingan tidak sehat dalam upaya penguasaan pangsa pasar terasa semakin memberatkan para pelaku UMKM yang kurang memiliki kemampuan bersaing karena perusahaan besar telah mulai merambah untuk menguasai bisnis dari hulu ke hilir.

Pelaku UMKM ataupun pelaku usaha besar dalam menjalankan usaha atau bisnisnya harus mengenal, memahami, dan memiliki etika dalam berusaha atau berbisnis. Etika bisnis sangat penting untuk para pelaku UMKM tidak hanya penting bagi pelaku usaha besar. Pengetahuan tentang etika bisnis penting untuk pencegahan atas pelanggaran-pelanggaran yang potensial dilakukan oleh para pelaku usaha.

Suatu pelanggaran adalah suatu keniscayaan. Persaingan yang ketat dan keras mendorong para pelaku usaha untuk melakukan pelanggaran demi mendapatkan keuntungan. Menjaga agar persaingan tetap sehat, Indonesia telah memiliki Undang-Undang Nomor 5 Tahun 1999 tentang Larangan Praktek Monopoli dan Persaingan Usaha Tidak Sehat. Berdasarkan ketentuan dari Undang-Undang Anti Monopoli, diatur beberapa perjanjian, kegiatan, dan bentuk posisi dominan yang dilarang untuk dilakukan oleh pelaku usaha.

Melihat kembali ketentuan Pasal 50 huruf h Undang-Undang Anti Monopoli yang menyebutkan dengan tegas bahwa yang dikecualikan dari ketentuan adalah pelaku usaha yang tergolong dalam usaha kecil. Ketentuan tersebut secara implisit maupun eksplisit memberi kesan bahwa pemberian pengecualian kepada pelaku usaha kecil dari ketentuan Undang-Undang Anti Monopoli bersifat mutlak atau absolut (absolute).

Pemberian pengecualian kepada pelaku usaha kecil tidak boleh bersifat absolut dan harus tetap ada batasan-batasan pelanggaranpelanggaran seperti apa yang dapat dikecualian dan pelanggaran-pelanggaran seperti apa yang dapat ditindak. Pemberian pengecualian kepada pelaku usaha kecil bukan berarti pelaku usaha kecil tidak bisa nakal terhadap pelaku usaha lainnya. Pelanggaran-pelanggaran yang potensial dilakukan oleh para pelaku UMKM dalam hal persaingan usaha sesuai yang telah diatur pada Undang-Undang Anti Monopoli adalah sebagai berikut:

\section{a) Penetapan Harga}

Penetapan harga pada suatu perkumpulan UMKM adalah nyata adanya, pelanggaran penetapan harga adalah pelanggaran yang potensial dilakukan oleh para pelaku UMKM berdasarkan pengamatan dan penelitian yang dilakukan dan juga atas konfirmasi yang dilakukan kepada KPPU. Antara para pelaku UMKM yang menjual produk sejenis melakukan kesepakan penetapan harga yang hampir sama, tidak memiliki perbedaan yang mencolok. Tidak hanya pada komunitas UMKM Mina Makmur $^{13}$ namun juga pada suatu pasar yang telah dikelompokkan barang dagangan yang untuk diperjualbelikan. Harga yang

13 Kelompok Usaha Bersama (KUB) "Mina Makmur" berdiri sejak 1988 yang merupakan sebuah kelompok usaha yang memproduksi bandeng presto, pepes bandeng presto, otak-otak bandeng, kerupuk udang, karak udang, dan beberapa makanan olahan ikan lainnya. Mina Makmur beralamat di Jalan Purwosari IV No. 17 RT 5 RW 3 Kel. Tambakrejo Kec. Gayamsari Semarang Jawa Tengah. KUB ini beranggotakan 70 anggota. 
ditawarkan oleh pedagang tidak memiliki perbedaan yang mencolok.

Salah satu jenis pelanggaran dalam penetapan harga adalah melalui diskriminasi harga. Di dalam Undang-Undang Nomor 5 Tahun 1999, diskriminasi yang berkaitan dengan harga diatur dalam dua kelompok aturan atau pasal, yakni diskriminasi harga yang disepakati di bawah payung perjanjian dan diskriminasi yang dilakukan secara sepihak atau tanpa perjanjian. ${ }^{14}$

\section{b) Boikot}

Boikot merupakan salah satu pelanggaran yang potensial dilakukan oleh pelaku UMKM. Komunitas para pedagang banyak dijumpai disetiap pasar atau wilayah tertentu. Boikot tidak bisa dilakukan oleh seorang pedagang tetapi dilakukan oleh beberapa pedagang yang tergabung dalam suatu komunitas tertentu karena boikot yang dilakukan oleh seorang pedagang tidak akan memberikan efek yang berarti. Boikot adalah suatu tindakan potensial yang dapat dilakukan para pelaku UMKM untuk menghilangkan pesaing yang mereka anggap mencuri konsumen mereka.

\section{c) Perjanjian dengan Pihak Luar Negeri}

Perjanjian dengan pihak luar negeri adalah salah satu bentuk pelanggaran yang juga potensial dilakukan oleh para pelaku UMKM. Keterbatasan pengetahuan membuat para pelaku UMKM dengan mudah melakukan perjanjian dengan pihak luar negeri yang dapat menimbulkan monopoli dan/atau persaingan usaha tidak sehat. Hal tersebut akan merugikan pelaku usaha kecil. Pemberian bantuan modal atau promosi ekspor ke luar negeri yang ditawarkan pihak luar negeri kepada para pelaku UMKM sah-sah saja, namun peraturan perundang-undang tidak mengijinkan karena masalah yurisdiksi dan berkaitan dengan penanaman modal asing. Terdapat beberapa ketentuan-ketentuan

14 Irwan Sugiarto, "Perspektif Ilmu Ekonomi Dan Undang-Undang Nomor 5 Tahun 1999 Tentang Larangan Praktik Monopoli Dan Persaingan Usaha Tidak Sehat Terhadap Diskriminasi Harga,” Jurnal Wawasan Yuridika 33, no. 2 (2017): 153. hukum yang tidak dapat dilakukan oleh pelaku usaha kecil.

\section{d) Pembagian Wilayah}

Perjanjian pembagian wilayah tanpa disadari dilakukan pelaku UMKM karena mereka mengamalkan istilah berikut "jangan mengganggu lahan orang”. Tindakan untuk tidak menjalankan usaha yang sama di wilayah yang sama dengan pesaing adalah suatu common sense bagi para pelaku UMKM. Tindakan tersebut tanpa disadari adalah suatu bentuk dari pembagian wilayah yang dilarang oleh peraturan perundangundangan. Pembagian wilayah dilakukan untuk menghindari terjadinya persaingan di antara para pelaku UMKM. Pembagian wilayah mengakibatkan hilangnya persaingan di antara sesama pelaku usaha. Pembagian wilayah membuat pelaku usaha melakukan tindakan pengurangan produksi ke tingkat yang tidak efisien kemudian melakukan eksploitasi terhadap konsumen dengan menaikkan harga produk dan menggunakan kekuatan yang dimiliki untuk bertindak sewenang-wenang terhadap konsumen yang sudah teralokasi sebelumnya. ${ }^{15}$

\section{e) Perjanjian Tertutup}

Pelanggaran dengan tying agreement menjadi pelanggaran yang potensial dilakukan oleh pelaku UMKM. Pelaku UMKM Mina Makmur yang menjual bandeng presto selalu menyertakan paket produk saus sambal merek lain (Merek X) yang tidak diproduksi bersama bandeng presto. Praktek tying agreement seperti ini akan merugikan konsumen yang tidak menyukai dengan saus sambal tersebut merek X tersebut. Harga saus sambal merek $\mathrm{X}$ tersebut sudah termasuk dalam harga paket bandeng presto tersebut sehingga konsumen mau tidak mau dengan saus sambal merek $\mathrm{X}$ tersebut harus membelinya. Praktek tying agreement telah menghilangkan hak konsumen untuk memilih secara merdeka jenis saus sambal yang ingin dibeli. Hal ini dapat

15 Elyta Ras Ginting, Hukum Antimonopoli Indonesia Analisis dan Perbandingan UU No. 5 Tahun 1999 (Bandung: Citra Aditya Bakti, 2001), hal 47 
menyebabkan persaingan tidak sehat dengan produsen saus sambal pesaing merek X.

Indikasi untuk dapat dilakukannya kegiatan-kegiatan pelanggran kegiatan berusaha sebagaimana yang diuraikan dalam Pasal 19 huruf d UU Anti Monopoli antara lain: 1) Adanya perlakuan istimewa yang dilakukan oleh pelaku usaha terhadap pelaku usaha tertentu, dan/atau 2) Perlakuan istimewa tersebut sama sekali tidak berdasarkan pertimbangan yang beralasan.

Adapun kriteria yang digunakan untuk membuktikan ada atau tidaknya monopoli yang dilarang tersebut didasarkan pada: ${ }^{16}$

a) Produk barang, jasa, atau barang dan jasa tersebut belum ada penggantinya (substitusinya);

b) Pelaku usaha lain sulit atau tidak dapat masuk ke dalam persaingan terhadap produk barang, jasa, atau barang dan jasa yang sama (barrier to entry);

c) Pelaku usaha lain tersebut adalah pelaku usaha yang mempunyai kemampuan bersaing yang signifikan dalam pasar yang bersangkutan;

d) Satu pelaku usaha atau satu kelompok usaha telah menguasai lebih dari 50\% pangsa pasar dari suatu jenis produk barang atau jasa tertentu.

Tidak semua kegiatan penguasaan atas produksi dan/atau pemasaran barang dan/atau jasa tergolong pada kegiatan yang dilarang, terkecuali sepanjang memenuhi unsur-unsur dan kriteria monopoli yang disebutkan dalam Pasal 17 Undang-Undang Anti Monopoli. Selain itu, jika pelaku usaha atau kelompok pelaku usaha dapat membuktikan sebaliknya yaitu kegiatan yang dilakukannya tidak memenuhi unsur-unsur dan kriteria Pasal 17, maka pelaku usaha atau kelompok usaha tersebut dengan sendirinya dapat terbebas dari kegiatan yang patut diduga atau dianggap sebagai monopoli.

Berdasarkan konfirmasi yang dilakukan kepada Kepala Biro Hukum, Humas, dan Kerjasama KPPU, sangat sulit seorang pelaku usaha melakukan monopoli dengan sempurna karena beberapa syarat dan ketentuan yang dijelaskan dalam Undang-Undang Anti Monopoli seperti yang tersebut di atas.

16 Susanti Adi Nugroho, 2012, Op Cit, hal 233-234

\section{Pengawasan Terhadap Pelaku Usaha Mikro Kecil dan Menengah (UMKM) di Thailand}

ASEAN telah memasuki kawasan Masyarakat Ekonomi ASEAN (MEA) oleh karenanya penting untuk melakukan harmonisasi hukum persaingan usaha di ASEAN, karena saat ini ASEAN telah memberlakukan perdagangan bebas melalui integrasi ekonomi diantara Negara Anggota ASEAN yang bertujuan untuk menghilangkan dan meminimalisir hambatan-hambatan yang akan timbul pada sektor kegiatan ekonomi.

Salah satu masalah yang mungkin akan timbul dari adanya pasar bebas (single market) ini ialah kasus persaingan usaha lintas batas negara, seperti hambatan vertikal (vertical restrain), kartel internasional (international cartel), dan merger lintas batas (cross-border marger). Melalui upaya harmonisasi, konflik diantara sistem hukum dapat diatasi dan juga perbedaan hukum dapat diminimalisir. Untuk melakukannya, ASEAN setidaknya butuh untuk menyelaraskan tiga bidang yang berbeda dari hukum persaingan usaha di Negara Anggota ASEAN, antara lain substansi hukum atau hukum materiil (larangan perjanjian antiPersaingan, larangan penyalahgunaan posisi dominan, larangan merger anti-Persaingan, pengecualian pada kepentingan publik), penegakan hukum atau hukum formiil (pendekatan hukum dan penerapan saksi), dan komisi persaingan usaha (pembentukan komisi persaingan di negara anggota dan mempunyai wewenang dalam menangani kasus-kasus antiPersaingan lintas batas negara di ASEAN). ${ }^{17}$

Sebagai bentuk komparasi sistem hukum persaingan usaha pada salah satu negara ASEAN lainnya, berikut adalah sistem perlindungan terhadap persaingan usaha tidak sehat di Thailand. Undang-Undang tentang UMKM Thailand diundangkan pada 6 Februari 2000, terdiri dari 48 Pasal dikenal dengan SMEs basic law. Undang-Undang ini mereduksi aturan untuk UMKM yang bersifat membatasi langsung UMKM dan cenderung hanya terbatas sebagai fasilitas. Undang-Undang UMKM ini juga memutuskan UMKM didesentralisasi ke

17 Fathari, M. R. (2018). Harmonisasi Hukum Persaingan Usaha Di Asean Dalam Kerangka Mea: Enforcement Cooperation (Doctoral Dissertation, Fakultas Hukum Universitas Umammadiyah Yogyakarta), hal 101 
Pemerintah lokal. Beberapa elemen dasar dalam Undang-Undang UMKM Thailand adalah: ${ }^{18}$

a) Komite Promosi Usaha Kecil dan Menengah dalam istilah internasionalnya dikenal dengan nama Office of Small and Medium Enterprises Promotion (OSMEP) ${ }^{19}$ diketuai oleh Perdana Menteri, wakilnya Menteri Perindustrian dengan jumlah anggota sebanyak 25 orang. OSMEP juga bertindak untuk mengawasi implementasi rencana dan kebijakan bagi UMKM.

b) OSMEP merupakan sebuah badan semi Pemerintah yang otonom dan bertanggung jawab untuk melakukan koordinasi dalam merumuskan rencana aksi promosi UMKM, mengelola dana promosi UMKM sesuai dengan peraturan perundang-undangan yang telah disepakati dan dibuat oleh OSMEP

c) Dana promosi UMKM digunakan untuk membantu UMKM dan membiayai kegiatan badan-badan Pemerintah atau organisasi swasta yang sudah disetujui oleh OSMEP.

Undang-undang persaingan usaha yang telah berlaku di Thailand saat ini yaitu Thailand Trade Competition Act 1999. Sejarah hukum persaingan usaha di Thailand bermula dari diundangkannya undang-undang Price Fixing and Anti Monopoly Act 1979. Undang-undang ini terdiri dari 2 bagian yaitu bagian penetapan harga (price fixing) dan anti monopoli. Thailand juga telah memiliki Komisi tersendiri dalam bidang Persaingan Usaha (Competition Commission). Komisi Persaingan Usaha di Thailand memantau implementasi dari UndangUndang Persaingan Usaha.

Terdapat perbedaan mencolok pada Hukum Persaingan Usaha antara Thailand dengan Indonesia kaitannya dengan pelaku UMKM. Hukum Anti Monopoli Thailand tidak memberikan pengecualian kepada pelaku UMKM dari ketentuan-ketentuan Hukum Anti

18 Diambil dari Makalah Organisasi UMKM \& Inovasi Regional Jepang (Organization for Small \& Medium Enterprises and Regional Innovation, Japan), Makalah dengan judul "Small \& Medium Enterprise Development Policies in Thailand”, hal 168 Diunduh dari http://www.smrj.go.jp/keiei/dbps_data/_material /common/chushou/b keiei/keieikokusai/pdf/SM E_in_ASEAN_E2_0803.pdf pada 13 Desember 2018 pukul 22:46 WIB

19 http://eng.sme.go.th/Pages/home.aspx
Monopoli Thailand. Hal ini membawa implikasi yang berbeda pada pengembangan UMKM di Thailand.

\section{KESIMPULAN}

Implikasi atas Pengecualian Usaha Kecil dalam Undang-Undang Nomor 5 Tahun 1999 tentang Larangan Praktek Monopoli dan Persaingan Usaha Tidak Sehat terhadap Pelaku Usaha Kecil adalah dengan bertambahnya jumlah pelaku usaha kecil (UMKM). Pertambahan jumlah pelaku UMKM adalah implikasi positif dari adanya pengeculian untuk pelaku UMKM di UU Anti Monopoli. Namun, selain implikasi positif juga terdapat implikasi negatif tentang pengecualian ini, yaitu para pelaku UMKM tidak ingin menjadi pelaku usaha besar, karena dengan menjadi pelaku usaha besar maka sudah tidak dikecualikan dari UU Anti Monopoli sehingga menuntut para pelaku usaha untuk lebih hati hati dalam menjalankan usahanya.

Bentuk Pelanggaran atas UndangUndang Nomor 5 Tahun 1999 tentang Larangan Praktek Monopoli dan Persaingan Usaha Tidak Sehat yang Potensial Dilakukan oleh Pelaku Usaha Mikro Kecil dan Menengah (UMKM) adalah Penetapan Harga, Boikot, Pembagian Wilayah, Perjanjian dengan pihak luar negeri, dan Perjanjian Tertutup.

Pengawasan terhadap Pelaku Usaha Mikro Kecil dan Menengah (UMKM) di Thailand memiliki beberapa instansi yang bertugas memberikan pengawasan terhadap pelaku UMKM yaitu: Office of Small and Medium Enterprises Promotion (OSMEP), Komisis Persaingan Usaha (Competition Commission), Institute for Small and Medium Enterprises Development (ISMED), Bank Pembangunan UKM Thailand (SMED Bank of Thailand), Pemerintah Daerah.

\section{UCAPAN TERIMA KASIH}

Puji Syukur Penulis panjatkan Kehadirat Tuhan Yang Maha Esa Allah SWT atas berkah rahmat dan hidayahnya, sehingga Penulis dapat menyelesaikan penulisan jurnal ilmiah ini. Terima kasih Penulis ucapan kepada Orang Tua penulis, serta seluruh kolega Penulis di Fakultas Hukum Universitas Negeri Semarang atas 
dukungan dan doanya dalam penulisan jurnal ilmiah ini.

\section{DAFTAR KEPUSTAKAAN}

Aristeus, S. (2018). Transplantasi Hukum Bisnis di Era Globalisasi Tantangan Bagi Indonesia. Jurnal Penelitian Hukum De Jure, 18(4), 513-524

Darmayoni, Ni Wayan Anggita dan Yusa, I Gede. "Merger Terkait Dengan Indikasi Penguasaan Pangsa Pasar Menurut Undang-Undang Nomor 5 Tahun 1999 Tentang Larangan Praktek Monopoli”. (1999)

Darmayoni, Anggita, and Jurnal Kertha Semaya. "Merger Terkait Dengan Indikasi Penguasaan Pangsa Pasar Menurut Undang-Undang Nomor 5 Tahun 1999 Tentang Larangan Praktek Monopoli Dan Persaingan Usaha Tidak Sehat." Universitas Udayana (2018).

Fathari, M. R. (2018). Harmonisasi Hukum Persaingan Usaha Di Asean Dalam Kerangka Mea: Enforcement Cooperation (Doctoral Dissertation, Fakultas Hukum Universitas Umammadiyah Yogyakarta)

Ginting, Elyta Ras. Hukum Antimonopoli Indonesia Analisis dan Perbandingan UU No. 5 Tahun 1999. Bandung: Citra Aditya Bakti, 2001.

Hermansyah. Pokok-Pokok Hukum Persaingan Usaha. Jakarta: Kencana, 2008.

http://eng.sme.go.th/Pages/home.aspx

http://www.depkop.go.id/

Irianto, Sulistyowati, Sidharta, and dkk. Metode Penelitian Hukum: Konstelasi dan Refleksi. Jakarta: Yayasan Pustaka Obor Indonesia, 2011.
Margono, Suyud. Hukum Anti Monopoli. Jakarta: Sinar Grafika, 2009.

Nugroho, Susanti Adi. Hukum Persaingan Usaha di Indonesia dalam Teori dan Praktik serta Penerapan Hukumnya. Jakarta: Kencana, 2012.

Organisasi UMKM \& Inovasi Regional Jepang (Organization for Small \& Medium Enterprises and Regional Innovation, Japan). "Small \& Medium Enterprise Development Policies in Thailand". http://www.smrj.go.jp/keiei/dbps_data/_ material_common/chushou/b_keiei/keiei kokusai/pdf/SME in ASEAN E2 0803.p $\underline{d f R o k a n, ~ M u s t a f a ~ K a m a l . ~ H u k u m ~}$ Persaingan Usaha Teori dan Praktiknya di Indonesia Cetakan ke-2. Jakarta: RajaGrafindo Persada, 2012.

Saptomo, Ade. Pokok-Pokok Metode Penelitian Hukum. Surabaya: Unessa University, 2007.

Sugiarto, Irwan. "Perspektif Ilmu Ekonomi Dan Undang-undang Nomor 5 Tahun 1999 Tentang Larangan Praktik Monopoli Dan Persaingan USAha Tidak Sehat Terhadap Diskriminasi Harga." Jurnal Wawasan Yuridika 33.2 (2016)

Wignjosoebroto, Soetandyo. Hukum: Paradigma, Metode dan Dinamika Masalahnya. Jakarta: Elsam \& Huma, 2002. 
• 